\title{
Determination of Procalcitonin, C-Reactive Protein and White Blood Cell Levels to Diagnose Community-Acquired Pneumonia (CAP)
}

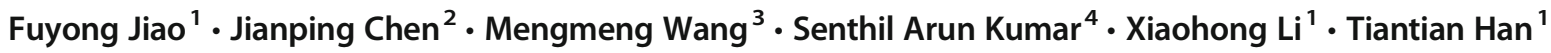

Received: 21 March 2018 / Accepted: 18 March 2019 / Published online: 4 April 2019

(C) Dr. K C Chaudhuri Foundation 2019

To the Editor: Pediatric community-acquired pneumonia (CAP), majorly caused by viral, bacterial and Mycoplasma pneumoniae (MP) infections, remains challenging for all the clinicians to differentiate and formulate treatment modalities, causing increasing mortality in young children [1-3]. The etiology of CAP is crucial for the physicians to initiate an effective treatment during early stages of pathogenesis of virus, bacteria and MP infections $[1,4]$. One of the major hurdles faced by the physicians is to differentiate bacteriamediated CAP from virus-mediated CAP during early stages of pathogen invasion, which in turn is crucial to prevent overuse of antibiotics $[1,4]$. Further, limitations recorded with other clinical diagnostic tests, as well as inconclusive results with the measured Procalcitonin (PCT), C-reactive protein (CRP) and White blood cell (WBC) levels to differentiate pediatric CAP $[1,4]$ has preceded us to conduct a two year (Jan 2015 through Dec 2016) follow-up examination study for $\mathrm{PCT}, \mathrm{CRP}$ and WBC measurements in the recruited CAP affected children $[\mathrm{n}$ (number) $=590$ patients, aged $<5 \mathrm{y}$ and $>5$ y] from the Shaanxi Province, China. In our study, in compliance with clinical manifestations of CAP, we were able to differentiate bacterial infected CAP patients $(n=152-196)$ from virus $(n=28-114)$ and MP $(n=35-65)$ infected patients based on the measured PCT, CRP and WBC levels. With this

Senthil Arun Kumar

senthil.ibt@gmail.com

1 Children's Hospital, Shaanxi Provincial People's Hospital of Xi'an Jiaotong University, Xi'an, People's Republic of China

2 Tianyou Children's Hospital, Guangdong, People's Republic of China

3 Department of Clinical Medicine, Xi'an Medical University, Xi'an, People's Republic of China

4 School of Biotechnology/Bioinformatics, D Y Patil Deemed to be University, CBD Belapur, Navi Mumbai, Maharashtra, India pre-determined positive cut-off range of PCT $>0.05 \mathrm{ng} / \mathrm{ml}$, $\mathrm{CRP}>8 \mathrm{mg} / \mathrm{L}$ and $\mathrm{WBC}>10 \times 10^{12} / \mathrm{L}$ in CAP patients [5], we found the bacteria (Streptococcus pneumoniae and Staphylococcus aureus) infected patients of both age groups $(<5 \mathrm{y}$ and $>5 \mathrm{y})$ showed increased PCT $(0.135-0.142 \mathrm{ng} / \mathrm{ml})$, CRP $(8.268-9.216 \mathrm{mg} / \mathrm{L})$ and WBC $\left(10.852-11.752 * 10^{12} / \mathrm{L}\right)$ levels compared with the virus (majorly respiratory syncytial virus and adenovirus) and MP infected groups. Also, the Mycoplasma-infected patients who showed increased PCT $(0.095-0.104 \mathrm{ng} / \mathrm{ml})$ levels compared with the virus infected groups, did not show any significant changes in either CRP or WBC levels. This indeed could facilitate an early diagnosis and treatment of bacteria and/or Mycoplasma mediated CAP over virus mediated CAP.

\section{Compliance with Ethical Standards}

Conflict of Interest None.

\section{References}

1. Esposito S, Principi N. Defining the aetiology of pediatric community-acquired pneumonia: an unsolved problem. Expert Rev Respir Med. 2019;13:153-61.

2. Ngocho JS, de Jonge MI, Minja L, et al. Modifiable risk factors for community-acquired pneumonia in children under 5 years of age in resource-poor settings: a case-control study. Tropical Med Int Health. 2019. https://doi.org/10.1111/tmi.13211.

3. Wallihan R, Ramilo O. Community-acquired pneumonia in children: current challenges and future directions. J Inf Secur. 2014;69:S8790.

4. Principi N, Esposito S. Biomarkers in pediatric-community acquired pneumonia. Int J Mol Sci. 2017;18. https://doi.org/10.3390/ ijms 18020447 .

5. Lee JY, Hwang SJ, Shim JW, et al. Clinical significance of serum procalcitonin in patients with community-acquired lobar pneumonia. Korean J Lab Med. 2010;30:406-13.

Publisher's Note Springer Nature remains neutral with regard to jurisdictional claims in published maps and institutional affiliations. 